\title{
Molecular Identification of Hg-Resistant Bacteria and Their Potential in Reducing Mercury Contamination
}

\author{
SORAYA FITRIA NASIR*, ANI M. HASAN**, ARYATI ABDUL, AND YULIANA RETNOWATI \\ Department of Biology, Faculty of Mathematics and Natural Sciences, Gorontalo State University, \\ Jalan Prof BJ Habibie, Bone Bolango Regency, 96554, Indonesia.
}

\begin{abstract}
The aim of this research was to obtain and determine the identity of $\mathrm{Hg}$-resistant bacteria in soil contaminated with gold processing waste and test its ability to reduce mercury contamination. Soil samples as a source of $\mathrm{Hg}$ resistant bacterial isolates were obtained from the gold processing location in Ilangata Village, Anggrek District, North Gorontalo Regency. The research was conducted at the Microbiology Laboratory, Department of Biology, Faculty of Mathematics and Natural Sciences. Mercury analysis was carried out at the Laboratory of Fisheries Product Quality Development and Testing (LPPMHP), Gorontalo Province, and bacterial identification was carried out at the Hasanuddin University Medical Research Center Research Unit. The parameters observed were the types of $\mathrm{Hg}$ resistant bacteria and the ability of the bacteria to reduce mercury contamination. The results showed that there were four bacterial isolates on the soil contaminated with $4.5 \mathrm{ppm}$ mercury, which were named ILb01, ILB02, ILb03, and ILb04. Molecular identification showed that ILb01 was closely related to Stenotrophomonas sp. SB67 and ILb02 close to Enterobacter cloacae strain CM 1, these strains were not resistant to mercury contamination; while ILb03 which is similar to Bacterium strain BS0591 and ILb04 which is similar to Bacillus albus strain SQ30 16S could be resistant and was able to reduce mercury contamination by $99 \%$ at 10 ppm levels.
\end{abstract}

Key words: heavy metals, Hg-resistant bacteria, molecular identification, mercury

Tujuan penelitian ini untuk mendapatkan dan menentukan identitas bakteri resisten $\mathrm{Hg}$ pada tanah terkontaminasi limbah pengolahan emas serta menguji kemampuannya untuk menurunkan cemaran merkuri. Sampel tanah sebagai sumber isolat bakteri resisten $\mathrm{Hg}$ diperoleh dari lokasi pengolahan emas Desa Ilangata, Kecamatan Anggrek Kabupaten Gorontalo Utara. Penelitian dilaksanakan di Laboratorium Mikrobiologi Jurusan Biologi Fakultas Matematika dan Ilmu Pengetahuan Alam. Analisis merkuri dilakukan di Laboratorium Pembinaan dan Pengujian Mutu Hasil Perikanan (LPPMHP) Provinsi Gorontalo dan identifikasi bakteri dilakukan di Unit Penelitian Hasanuddin University Medical Research Center. Parameter yang diamati adalah jenis bakteri resisten $\mathrm{Hg}$ dan kemampuan bakteri dalam menurunkan cemaran merkuri. Hasil penelitian menunjukkan terdapat empat isolat bakteri pada tanah terkontaminasi 4.5 ppm merkuri yang diberi nama ILb01, ILB02, ILb03, dan ILb04. Identifikasi molekuler menunjukkan ILb01 memiliki kedekatan dengan Stenotrophomonas sp. SB67 dan ILb02 dekat dengan Enterobacter cloacae strain CM 1, dua galur bakteri tidak resisten terhadap cemaran merkuri; sementara ILb03 yang mirip dengan Bacterium strain BS0591 dan ILb04 yang mirip dengan Bacillus albus strain SQ30 mungkin resisten terhadap merkuri dan mampu menurunkan cemaran merkuri sebesar $99 \%$ pada kadar 10 ppm.

Kata kunci: bakteri resisten $\mathrm{Hg}$, identifikasi molekuler, logam berat, merkuri

The mining industry is an important industry that contributes economic and social benefits and accelerates development in an area. One of the potential gold mines that is still operating today is in North Gorontalo Regency which is dominated by traditional mining. Traditional gold mining activities have big potential to produce waste that will damage the environment. The process of refining gold using mercury or amalgamation can cause environmental pollution because the leaching results are discharged into water bodies.

*Corresponding author: Phone: +62-82293272739; E-mail: oyafitria@gmail.com, animhasan@ung.ac.id
Mercury is a type of pollutant that needs attention because it is a heavy metal that has strong toxic properties. Mercury that enters water bodies has an impact on the environment. Mercury that enters the environment undergoes precipitation and is converted by microorganisms into methyl mercury. The presence of methyl mercury in the waters has a bad impact because it will accumulate in the body of the biota that live in the waters and has the potential to cause disturbances in the body's organs and metabolism of the biota. Saleh et al. (2014), reported methyl mercury that enters the waters will accumulate in zooplankton or phytoplankton which then through the food chain will accumulate in fish bodies. This accumulation of 
mercury causes dysfunction in the body parts of the fish and even causes death.

Therefore, prevention efforts are needed from an early age to overcome pollution. According to Haritash and Kaushik (2009), methods of remediation of polluted environments in conventional ways, namely physically (incineration and washing) and chemically (chemical reactions, dilution and extraction) are considered only as a process of moving a pollutant from one place to another. The biological method of remediation (bioremediation) is a method that is environmentally friendly and occurs naturally. Bioremediation is an alternative solution to environmental problems due to heavy metal pollution in mining areas. Various types of bacteria isolated from contaminated areas are known to be potential good bioremediator agents because they can reduce high levels of heavy metals in laboratory experiments.

Some bacteria that have the ability to adapt to environments contaminated with heavy metals can help the process of restoring the environment with a remediation mechanism. This is because these bacteria have the ability to resist high contamination of heavy metals. Freetes et al. (2019) explained that bacteria that are able to survive at high concentrations of heavy metals can eliminate toxic effects in contaminated areas. Bacteria that have the ability to eliminate these toxic effects have the potential to act as bioremediating agents in the environment.

Various types of bacteria can be used to remediate heavy metals as stated by Lutfi et al. (2018), obtained by bacteria Morganella morganii isolated from mining areas and can be a bioremediator agent against mercury because it can reduce mercury levels by up to $92.46 \%$ at a Hg concentration of $130 \mathrm{ppm}$. In Rondonuwu's (2012) study, there were 10 bacterial isolates that could grow and reduce mercury in farming luria media. Four of the isolates were from the Bacillus sp. with the ability to reduce levels of $52 \%$ to $98 \%$. Apart from that, from the gram-negative group of bacteria, namely Micrococcos luteus, Brevibacillus sp., Morganella morganii, Eschericia and Pseudomonas sp. able to reduce mercury levels by $53 \%$ to $98 \%$.

The purpose of this study was to determine the potential bacteria as a bioremediator agent in soil contaminated with gold mining waste in Ilangata Village, Anggrek District, North Gorontalo District and the ability of these bacteria to reduce mercury contamination.

\section{MATERIALS AND METHODS}

Soil Sampling. Soil sampling was carried out at the gold processing plant in Ilangata Village, Anggrek District, North Gorontalo Regency at three points using purposive sampling technique which has high mercury content because it is located very close to the gold processing waste disposal site. Soil samples were taken and composited then put into sterile adhesive plastic samples.

Isolation and Purification of Bacteria. Bacterial isolation was carried out at the Microbiology Laboratory, Department of Biology, F.MIPA, Gorontalo State University by following the procedure of Amelia, et al (2016) by taking a sample that has been weighed as much as 1 gram and diluted with $9 \mathrm{ml}$ of distilled water. The dilutions were carried out in a series from $10^{-1}$ to $10^{-5}$. The sterilized NA media is poured sufficiently into the petri dish. After that, as much as $0.5 \mathrm{ml}$ from the $10^{-1}$ dilution to the $10^{-5}$ put into a petri dish containing the medium and then homogenized. The petri dishes were wrapped in paper and incubated for 48 hours at $37^{\circ} \mathrm{C}$. Furthermore, the bacterial suspension was prepared by diluting it with sterile distilled water. Sterile aquades were put into each test tube as much as $10 \mathrm{ml}$ and then put in 4 ose bacterial colonies and then homogenized. After that, the four tubes were equalized with a standard solution of Mc Farland 0.5 ( $\left.1 \times 10^{8} \mathrm{CFU} / \mathrm{ml}\right)$ (Quelab 2005). The growing bacteria were then purified by the scratch method on Nutrient agar media.

Bacterial Resistance Test. The resistance test was carried out using heavy metal mercury by inserting $1 \mathrm{ml}$ of bacterial suspension which had a cell density of $10^{8}$ into a petri dish containing a medium with heavy metal mercury in concentration of $10 \mathrm{ppm}, 20 \mathrm{ppm}, 30 \mathrm{ppm}$, $40 \mathrm{ppm}$ and $50 \mathrm{ppm}$. This resistance standard was taken based on the results of the analysis of the soil content of gold mining waste by the Gorontalo Province LPPMHP which was at $4.5 \mathrm{ppm}$. Petri dishes were wrapped in paper and incubated for 48 hours at $37^{\circ} \mathrm{C}$.

Bacteria identification. The identification of bacteria was carried out at the Hasanuddin University Medical Research Center Research Unit with a DNA extraction process then carried out by the DNA amplification process with a PCR machine (Polymerase Chain Reaction). DNA extraction was carried out using the spin column method. The DNA amplification process was carried out by taking $25 \mu \mathrm{L}$ of Kappa brand PCR Master mix (Composition: Enzyme Taq Polymerase, Buffer, dNTP, $\left.\mathrm{MgCL}_{2}\right), 1.5$ 
$\mu \mathrm{L}$ Forward Primer (63F: CAGGCCTAACATGC AAGTC), and $1.5 \mu \mathrm{L}$ of Reverse Primer (1387R: GGGCGGTGTGTACAAGGC), $16 \mu \mathrm{L}$ of Nuclease Free water and $6 \mu \mathrm{L}$ of isolated DNA into each $0.2 \mathrm{~mL}$ tube (PCR tube). Close the PCR tube to then spin down then insert it into the Thermal Cycler machine (PCR machine) with the PCR machine protocol, namely: initial denaturation of 1 cycle at $95^{\circ} \mathrm{C}$ for 5 minutes. Then denaturation at $95^{\circ} \mathrm{C}$ for 10 seconds, annealing at $60^{\circ} \mathrm{C}$ for 5 seconds and extention at $72^{\circ} \mathrm{C}$ for 5 seconds. These three processes occur for 40 cycles. Finally, final extension at $72{ }^{\circ} \mathrm{C}$ for 5 minutes for 1 cycle. The electrophoresis process was carried out to see the length of the bands on each bacterial isolate using agarose and then visualized it under UV light. The results of PCR products that have bands are carried out sequencing analysis at First Base-Singapore then the sequencing results are carried out by BLAST analysis to compare with the existing data base on Gen Bank by accessing the web: https://www.ncbi.nlm.nih.gov .

Test the ability of bacteria to reduce mercury contamination. The bacterial isolates were then tested for their ability to reduce mercury contamination by inoculating $10 \mathrm{ml}$ of bacterial suspension in Nutrient Broth medium containing a concentration of $10 \mathrm{ppm}$ $\mathrm{HgCl}_{2}$ then incubating in an incubator shaker at a speed of $100 \mathrm{rpm}$ for 24 hours. Furthermore, centrifugation was carried out for 5 minutes at a speed of $5000 \mathrm{rpm}$. The supernatant was analyzed by AAS to determine the metal concentration that had decreased (Amelia et al, 2016). Testing for mercury levels is carried out by testing for levels of mercury $(\mathrm{Hg})$ carried out at the Laboratory of Fisheries Product Quality Development and Testing (LPPMHP) in Gorontalo Province using SNI 01-2354.6-2006 standards for solid samples and SNI 6989.78: 2011 standards for liquid samples. The principle of the test for mercury levels is that the $\mathrm{Hg}^{2+}$ will be reduced by $\mathrm{Sn}^{2+}$ to $\mathrm{Hg}$. Then the atoms were analyzed quantitatively by cold-vapor Atomic Absorption Spectrophotometry or Mercury Analyzer using a wavelength $(\lambda)$ of $253.7 \mathrm{~nm}$.

Calculation of the decrease in mercury levels. The reduction in heavy metal content can be calculated using the Dimawarnita formula (2017):

$$
\alpha_{s}=\left(1-\frac{c_{s}}{c_{0}}\right) \times 100 \%
$$

where: $\alpha_{s}$ is the percentage of metal reduction; Cs is the final metal concentration (ppm); Co is the initial metal concentration (ppm).

\section{RESULTS}

Macroscopic Characteristics of Bacteria. Based on the results of isolation carried out on soil contaminated with heavy metal mercury, four bacterial isolates were obtained which were morphologically different based on macroscopic observations (Fig 1). In ILb01 the colony obtained was yellow with a texture that was stickier than the other bacterial isolates obtained. The colonies are round in shape with intact edges. In ILb02, bacterial colonies appear white with intact and rounded edges. The colony surface looks flat and has a hard and dry texture whereas ILb03 and ILb04 have almost the same morphology, namely white with wavy edges, flat surface and hard and dry texture, but in terms of shape ILb03 has a similar shape to roots while ILb04 has irregular colony forms (Table 1).

Identification of Bacteria. Molecular identification of bacteria can be done using the Polymerase Chain Reaction (PCR) technique. The sequencing process is to determine the nucleotide sequence present in the DNA fragment detected by PCR amplification. The nucleotide sequence obtained was then analyzed by BLAST by matching it to the Gen Bank. From the four bacterial isolates, it was found that the bacterial isolates were detected to have a band at 996 bp (Fig2).

Based on the reconstruction of the phylogenetic tree, it is known that ILb01 and ILb03 are in the same branch or originate from the same ancestor but then form different branches. ILb01 is related to ILb03 but is not in the same clade. ILb01 is phylogenetically located in the same clade as Stenotrophomonas sp. SB67. Meanwhile ILb03 seems to form its own branch which looks closer to Bacterium strain BS0591. In other branches also form a branch that separates the two nodes. One node forms a branch that connects the clade between ILb02 and Enterobacter cloacae strain CM 1 16S while the other node shows the closeness between ILb04 and Bacillus albus strain SQ30. However, these two bacteria come from the same ancestor as seen from their main branching (Fig 3).

Bacterial Resistance Test. The results showed that ILb03 and ILb04 could grow in media containing 10 ppm $\mathrm{HgCl}_{2}$ but at higher concentrations they could not survive. Meanwhile ILb01 and ILb02 were unable to grow at the all $\mathrm{HgCl}_{2}$ concentrations given (Table 2).

The Ability of Bacteria to Reduce Mercury Contamination. Based on the results of the analysis of the reduction in mercury contamination carried out by inoculating two isolates of mercury resistant bacteria, 
A

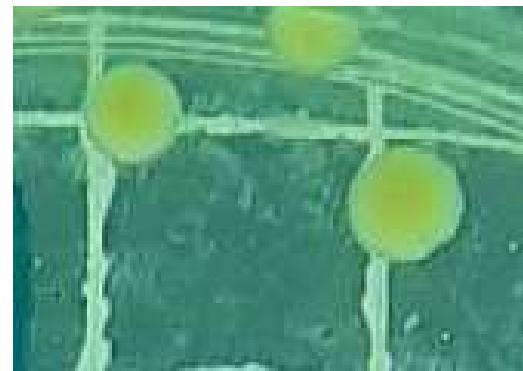

$\mathrm{C}$

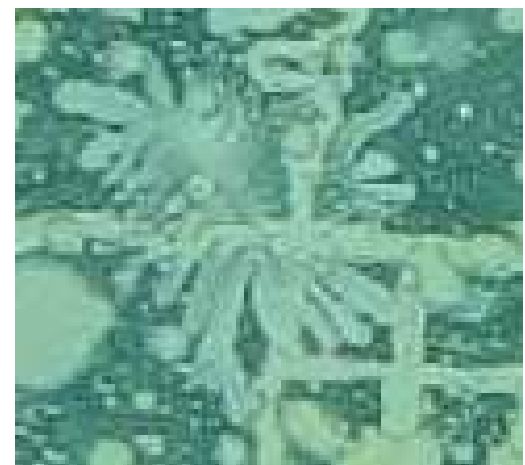

B

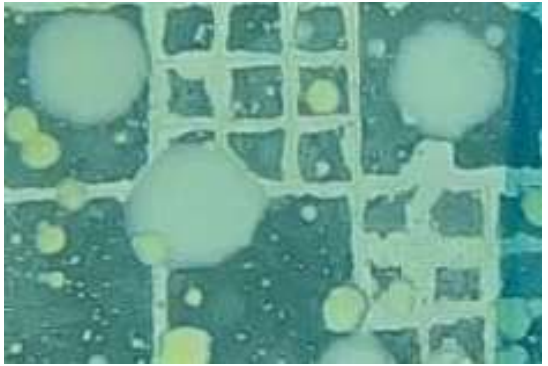

$\mathrm{D}$

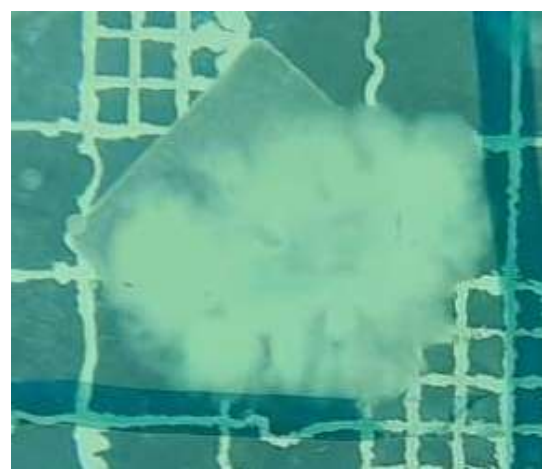

Fig 1 Morphology of colony bacterial isolates from soil samples; A) Bacteria Ilangata 01 (ILb01); B) Ilangata Bacteria 02 (ILb02); C) Ilangata Bacteria 03 (ILb03); D) Ilangata Bacteria 04 (ILb04).

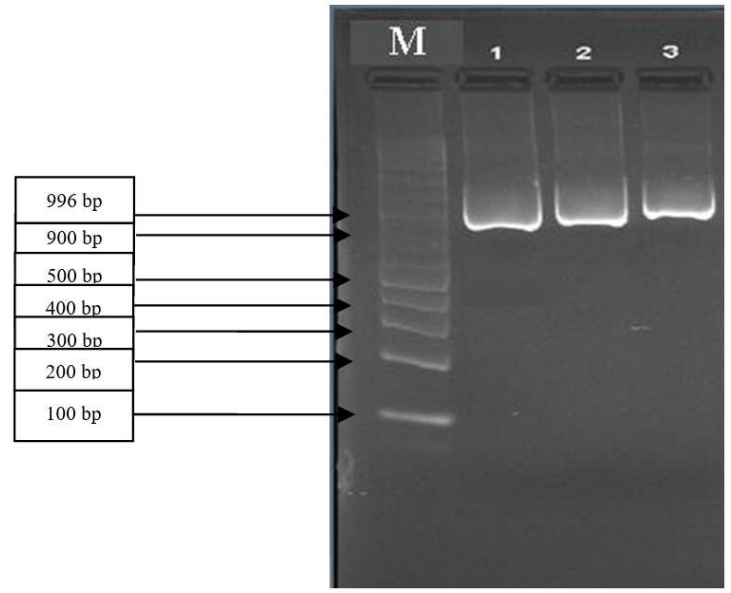

Fig 2 Electrophoresis results of bacterial isolates with 63F and 1378F DNA marker primers of 100bp.

namely ILb03 and ILb04 into medium containing Nutrient broth $10 \mathrm{ppm}$ mercury, it was found that the two isolates could reduce the mercury content by $99 \%$ for 24 (Table 3).

\section{DISCUSSION}

Gold processing using the amalgamation method is one of the gold laundering methods using mercury metal. These activities produce waste that contains mercury and is released into the environment. This mercury metal pollution causes water and soil quality to decline and can affect the biota that lives around it.

The land for disposal of waste from gold processing is known to have a large mercury content because the gold laundering process is still carried out by amalgamation using mercury. The results of the LPPMHP analysis of Gorontalo Province show that the soil around the gold processing is contaminated with high mercury because it contains mercury levels between $2.6-4.5 \mathrm{ppm}$. This concentration is quite high because according to Alloway in Mirdat et al. (2013), the concentration of heavy metal $\mathrm{Hg}$ in soil and plants is in the normal range is $0.01-0.3 \mathrm{ppm}$, while in the critical range of $0.3-0.5 \mathrm{ppm}$.

Based on molecular identification, it was found that ILb01 has a kinship relationship with Stenotrophomonas sp. SB67 (Acc. DM065750.1). ILb02 can be seen to have a kinship relationship with Enterobacter cloacae strain CM 1 16S (Acc. KC920908.1) because it is in one node that forms the same clade. In ILb03, a phylogenetic tree is obtained, 
Table 1 Colonies bacterial isolates character in macroscopic

\begin{tabular}{cccccc}
\hline \multirow{2}{*}{ Isolate Name } & Colour & Edge & Shape & Surface & Texture \\
\hline ILb01 & Yellow & Whole & Round-flat & Arise & Soft \\
ILb02 & White & Whole & Round & Flat & Hard and dry \\
ILb03 & White & Wavy & Similar roots & Flat & Hard and dry \\
ILb04 & White & Wavy & Irregular & Flat & Hard and dry \\
\hline
\end{tabular}

Table 2 Resistance test for bacterial isolates of soil samples

\begin{tabular}{ccccccc}
\hline \multirow{2}{*}{ Isolate Name } & \multicolumn{7}{c}{ Concentration of $\mathrm{HgCl}_{2}(\mathbf{p p m})$} \\
& $\mathbf{0}$ & $\mathbf{1 0}$ & $\mathbf{2 0}$ & $\mathbf{3 0}$ & $\mathbf{4 0}$ & $\mathbf{5 0}$ \\
\hline $\mathrm{ILb01}$ & + & - & - & - & - & - \\
$\mathrm{ILb02}$ & + & - & - & - & - & - \\
$\mathrm{ILb03}$ & + & + & - & - & - & - \\
$\mathrm{ILb04}$ & + & + & - & - & - & - \\
\hline
\end{tabular}

Information: $+=$ growing bacteria

Table 3 Decrease in mercury contamination for 24 hours without replication

\begin{tabular}{cccc}
\hline Isolate Name & Initial Hg(ppm) & Final Hg(ppm) & $\begin{array}{c}\text { Percentage of } \\
\text { reduction (\%) }\end{array}$ \\
\hline ILb03 & 10 & 0.0342 & $99.658 \%$ \\
ILb04 & 10 & 0.0403 & $99.597 \%$ \\
\hline
\end{tabular}

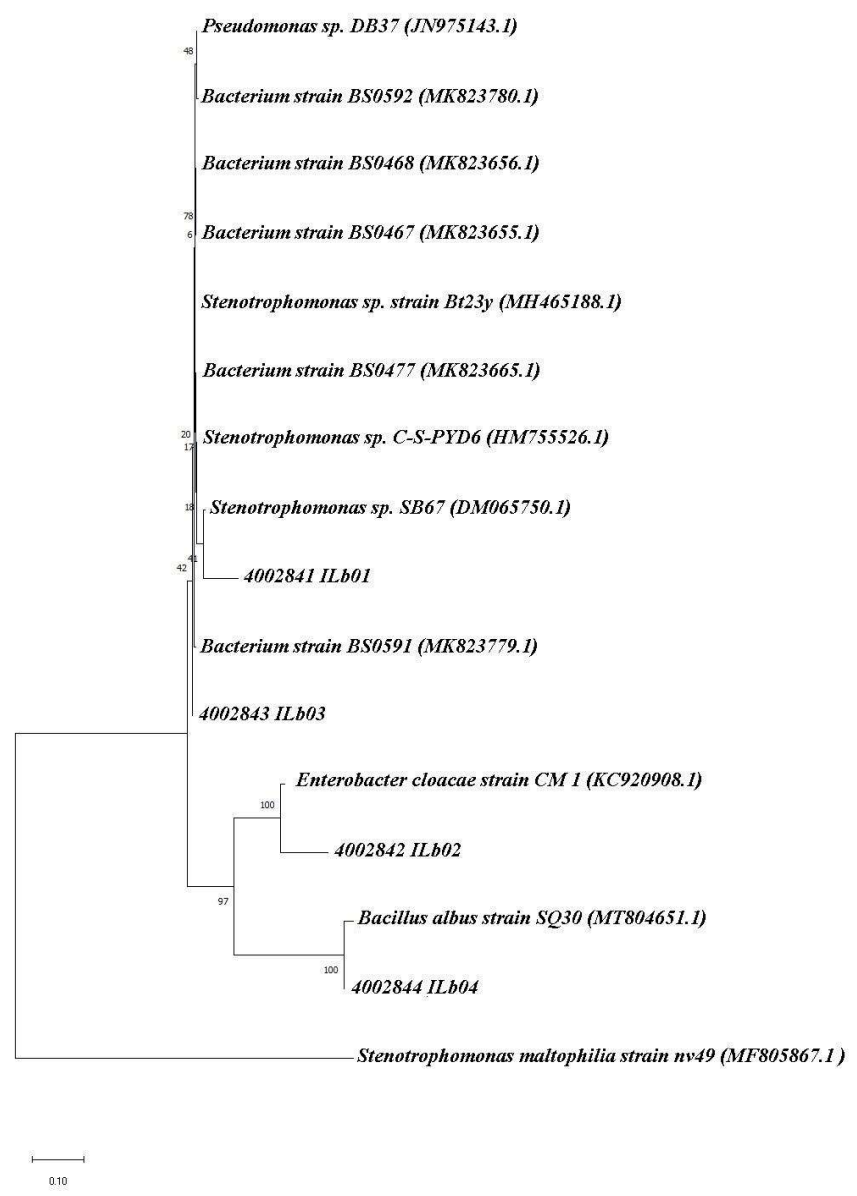

Fig 2 Neighbor-joining phylogenetic trees. Bootstrap value shows the percentage of 1000 replications. 
which shows that ILb03 forms its own branches and is not on the same branches or nodes as the bacteria present in the phylogenetic tree. ILb03 forms a branch that is closer to the Bacterium strain BS0591 (Acc.MK823779.1). Meanwhile, ILb04 seen from the existing phylogenetic tree has a very close relationship with Bacillus albus strain SQ30 because it is in the same clade.

The potential of bacteria in reducing mercury contamination can be seen from their resistance ability in conditions containing mercury metal contamination. Four isolated bacterial isolates were subjected to resistance tests at levels of 10 to $50 \mathrm{ppm}$ for 48 hours on Nutrient Agar media to show that ILb03 which is similar to Bacterium strain BS0591 and ILb04 which has similarities to Bacillus albus strain SQ30 is mercury resistant bacteria because it shows growth in media containing $10 \mathrm{ppm} \mathrm{HgCl}_{2}$ but at higher concentrations cannot survive. Meanwhile, ILb01 has similarities with Stenotrophomonas sp. and ILb02 which has similarities with Enterobacter cloacae strain CM 1 showed no growth at the five concentrations of $\mathrm{HgCl}_{2}$ given. The ability of ILb03 and ILb04 resistance can be caused because these bacteria can develop resistance mechanisms against heavy metals such as absorption of heavy metals in the cell wall, metal immobilization in the bioleaching mechanism and the involvement of operon genes in the biotransformation mechanism. Meanwhile, bacteria that are unable to grow at higher levels is thought to be because bacteria have a limited ability to tolerate mercury metal. When bacteria are unable to develop a resistance mechanism against heavy metals, death will occur due to not being able to tolerate the presence of mercury contamination. This difference in resistance ability can also occur because each bacterial isolate has a different response mechanism to keep growing in mercury-contaminated conditions. Bacterial isolates that are not resistant are thought to be due to inhibited cell metabolic processes so that growth does not occur and even death.

The ability to develop a resistance mechanism against heavy metals makes these bacteria have the ability to reduce contamination. This resistance mechanism can occur in several mechanisms such as biosopsy or bioaccumulation. In addition, it can also occur with the involvement by the gene mer operon.

ILb04 which has similarities with Bacillus albus also has a biosorption or bioaccumulation mechanism as well as a mechanism involving the mer operon gene. In Sholikhah and Nengah (2012), the ability of the genus Bacillus can occur through the biosorption and bioaccumulation processes. The interaction between metal ions and the cell wall of gram-positive bacteria shows the role of carboxyl groups on peptidoglycan and phosphoryl groups in the secondary polymers of teichoic and theicuronic acids. In addition, it can occur because $\mathrm{Hg}^{2+}$ binds to the negatively charged ions that make up peptone and meat extract in media Nutrient Broth. The components of this media Nutrient broth are protein groups. One of the functional proteins is the metalloprotease enzyme, which is a protein degrading which requires metal ions in its metabolic activity so that the metal ions in the medium are reduced. In Prasetya et al. (2017) also obtained results that in the genus Bacillus tested there was the involvement of the enzyme mercury reductase encoded in mer A with the help of NADH.

The mechanism of mercury reduction, which is an enzymatic reduction process or change to a non-toxic compound, has something to do with the involvement of mercury-resistant genes or operon mer. This is because the operon mer consists of genes that can convert toxic compounds such as methyl mercury into enzymatically non-toxic compounds. $\mathrm{Hg}^{2+}$ will be reduced to $\mathrm{Hg}^{0}$ assisted by NADPH as a cofactor for enzymatic processes. According to Vetriani et al. (2005), mercury resistant bacteria have operon mer which codes for flavoenzymes then mercury reductase reduces Hgions ${ }^{2+}$ to $\mathrm{Hg}^{0}$ which is non-toxic and volatile.

The ability of bacterial resistance to contaminated environmental conditions by developing resistance mechanisms such as absorption by means of biosorption or bioaccumulation and biotransformation mechanisms by involving the mer operon gene causes the bacteria to be able to reduce large mercury contamination so that it can make these bacteria potential as bioremediator agents for environmental recovery especially in mining areas.

\section{REFERENCES}

Amelia, Titik Fadilah, Ace Baehaki and Herpandi. 2016. Aktivitas Reduksi Merkuri pada Bakteri yang diisolasi dari air dan Sedimen di Sungai Musi. [Mercury Reduction Activity in Bacteria isolated from water and sediments in the Musi River]. J. Fishery Product Technol. 5 ( 1 ) : 94 - 106 . do i : 10.36706/fishtech.v5i1.3522.

Dimawarnita, Firda. Tri Panji and Suharyanto. 2017. Biosorpsi ion merkuri menggunakan jamur pelapuk putih imobil [Mercury ion biosorption using 
immobilized white rot fungi]. Plantation J. 85 (1): 2836. doi: 10.22302/iribb.jur.mp.v85i1.227.

Freetes, Charlie Ester de., Lies Indah Sutiknowati and Dede Falahudin. 2019. Isolasi dan Identifikasi Bakteri Toleran Logam Berat dari Sedimen Mangrove di Pengudang dan Tanjung Uban, Pulau Bintan Indonesia [Isolation and Identification of Heavy Metal Tolerant Bacteria from Mangrove Sediments in Pengudang and Tanjung Uban, Bintan Island, Indonesia]. Indones $\mathrm{J}$ Oceanol Limnol. 4 (71): 75-76. doi: 10.14203/oldi.2019.v4i2.244.

Haritash, AK and CP Kaushik. 2009. Biodegradation aspects of Polycyclic Aromatic Hydrocarbons (PAHs): A review. J Hazardous Materials. Page: 1-15. doi: 10.1016/j.jhazmat.2009.03.137.

Lutfi, Saundra Rosallina., Wignyanto and Evi Kurniati. 2018. Bioremediasi Merkuri Menggunakan Bakteri Indigenous dari Limbah Penambangan Emas di Tumpang Pitu, Banyuwangi [Mercury Bioremediation Using Indigenous Bacteria from Gold Mining Waste in Tumpang Pitu, Banyuwangi]. J. of Agric Technol. 19 (1): 15-24. doi: 10.21776/ub.jtp.2018.019.01.2.

Mirdat, Yosep S. Patadungan and Isrun. 2013. Status Logam Berat Merkuri (Hg) Dalam Tanah Pada Kawasan Pengolahan Tambang Emas di Kelurahan Poboya, Kota Palu [Status of Heavy Metal Mercury ( $\mathrm{Hg})$ in Soil in the Gold Mining Processing Area in Poboya Village, Palu City]. Agrotechbists. 1 (2): 128.

National Standardization Agency. SNI 01-2354.6-2006. Chemical Test Method - Part 6: Determination of Heavy Metal Mercury (Hg) Content in Fishery Products.

National Standardization Agency. SNI 6989.78: 2011. Water and Wastewater - Part 78: How to Test Mercury $(\mathrm{Hg})$ by Atomic Absorption Spectrophotometry (AAS) - Cold steam or Mercury Analyzer.

Prasetya, Yulianto Ade., Nengah Dwianita Kuswytasari and Enny Zulaikha. 2017. Potensi Genera Bacillus dari Kalimas Surabaya sebagai Agen Bioremediasi Pencemaran Merkuri [Potential of Genera Bacillus from Kalimas Surabaya as Bioremediation Agent of Mercury Pollution]. National Seminar on Science and Technology IV. Mercu Buana University.

Quelab. 2005. Mc Farland Standars. www.quelab.com

Rondonuwu, Sendy Beatrix. 2012. Bioremediation of waste containing mercury using local bacteria with a Bioreactor System and Artificial Wetlands. [Dissertation]. Bogor (ID): Bogor Agricultural University.

Saleh, Baskara Adam., Boedi Setya Rahardja and Muhammad Arief. 2014. Studi Kandungan Logam Berat Merkuri (Hg) dan Prediksi Kandungan Metil Merkuri $\left(\mathrm{CH}_{3} \mathrm{Hg}\right)$ pada Organ Kerang Darah (Anadara granosa) di Kecamatan Sidayu dan Kecamatan Bayuurip, Pantai Utara Gresik, Jawa Timur [Study of Heavy Metal Mercury (Hg) Content and Prediction of Methyl Mercury $\left(\mathrm{CH}_{3} \mathrm{Hg}\right)$ in Blood Shell Organ (Anadara granosa) in Sidayu and Bayuurip Districts, Gresik North Coast, East Java]. Fisheries and Marine Scientific J. 6 (2): 210-212. 10.20473/jipk.v6i2.11310.

Sholikhah, Umi and Nengah Dwianita Kuswytasari. 2012. Uji Potensi Genera Bacillus sebagai Bioakumulator Merkuri [Potential Test of Genera Bacillus as Bioaccumulator of Mercury]. Journal of the November Ten Institute of Technology.

Ventriani, Costantino., Yein S. Chew, Susan M. Miller, Jane Yagi, Jonna Coobs, Richard A. Lutz and Tamar Barkay. 2005. Mercury Adaptation among Bacteria from a Deep Sea Hydrothermal Vent. Appl Environ Microbiol. 71 (1): 224. doi: 10.1128/AEM.71.1.220-226.2005. 